\title{
Basic Level Thinking in the Textbook of the Primary School Early Class
}

\author{
Nurchasanah Nurchasanah ${ }^{1 *}$; Suyono Suyono ${ }^{1}$; and Zakia Habsari ${ }^{1}$
}

\author{
${ }^{1}$ State University of Malang, Indonesia \\ Corresponding author: nurchasanah.fs@um.ac.id; suyono.fs@um.ac.id; zakiahabsari23@gmail.com
}

\begin{abstract}
Thinking is one of the concerns of the 2013 curriculum which is shown by the demand that students can think at a high level. However, the basic level of thinking should get attention because the quality of basic level thinking determines the achievement of high-level thinking. With that consideration, this research aimed to describe the representation of basic level thinking in the thematic textbook of primary school in the first and second level of class. This research uses a qualitative design with content analysis as the type of research. The research data task in the textbook represented the demands of thinking on the basic level. The data was taken from the documentation technique and it was analyzed by procedures (1) data presentation, (2) data reduction, (3) data processing based on the data analysis guide instrument, (4) result inference, and (5) result interpretation. The result shows that the primary school textbook of the first and second level of the class represents the variation of basic level thinking that varied in the form of observing, identifying, remembering, copying, and composing.

Keywords: thinking, basic level thinking, textbook, a primary school textbook
\end{abstract}

\section{INTRODUCTION}

Thinking has a different gradation. In learning, the quality of thinking of students also has a different gradation. There are students who can only think at a basic level, some are already able to think up to a high level. Nurchasanah, Suyono, Lestari, and Habsari say that humans have a virtue that is not owned by other creatures which is thinking [1]. For normal humans, their behavior and language are always guided by their thoughts besides their feelings. Eanes [2], Suyono [3], and Nurchasanah [4] say that thinking always accompanies human behavior, including language. However, the quality of human thinking is varied and graded from basic (literal) to high-level (criticalcreative) thinking [4 and 5].

Literal thinking is basic level of thinking [6]. In language activities, for example reading and listening, literal thinking is shown by the behavior of recognizing and remembering what is read/listened to. Critical thinking is demonstrated by the behavior of reorganizing, inferring, evaluating, and appreciating what is read/listened to. Meanwhile, creative thinking is shown by the creative behavior that is read/listened to [4 and 5].

In learning, the quality of thinking becomes the center of attention. The Ministry of Education and Culture [7] demands that learning prioritizes the quality of thinking so students can think at a high level after character development and strengthening. Moreover, learning in elementary school, the quality of thinking needs to be considered. Considering that elementary school is a determinant of further education, elementary schools must prioritize the quality of thinking of students after the quality of their character. The quality of thinking is one of the centers of attention in learning studies, including the preparation of textbooks.

Textbooks are multifunctional. Textbooks are functioned as learning resources, teaching materials, and learning media [8]. Anglin [9] stated that textbooks serve as a guide for teachers, students, and as an evaluation tool for mastery of learning outcomes. Cunningsworth [10] said that textbooks have an influence on the learning atmosphere. In addition, Yustesia [11] said that textbooks become a source of information and learning resources for students so it will determine the achievement of learning outcomes. Therefore, the demands of thinking quality in textbooks need to get the attention, especially at the basic level of thinking (literal) because it will determine the quality of thinking at the next level. Horsley and Sikorova in 2014 stated that the results of the TIMSS (Trends in Mathematics and Science Study) survey of classroom learning prove that textbooks still play an important role as sources of learning in the classroom apart from political claims that digital learning resources are a means of teaching in future. This is evident that in $2011,70 \%$ of schools still used textbooks as learning resources [12].

As a learning resource, textbooks are expected to teach students to be able to think at a higher level. Therefore, the quality of thinking in textbooks needs to get attention, especially the level of thinking at the basic level (literal) because the quality of thinking at the basic level will determine the quality of thinking at the next level. 
Although elementary school textbooks play an important role in learning, the quality of the demands of thinking that are represented by those textbooks are not known yet until today, especially elementary school textbooks for early grades (Grades 1 and 2). Because of the elementary school is the basis of further education, the demands of thinking at the basic level in textbooks need to be assessed in order to know the appropriateness of books as a learning tool for target students.

In literacy activities, thinking has a graded level of difficulty. Barrett [13] divides the level of thinking in reading comprehension of five behaviors, namely literal understanding, reorganization, inferential, evaluation, and appreciation. In reading activities, Nurhadi [5] divided cognitive thinking into three categories which are literal, critical, and creative understanding. Based on the consideration of the views of Barrett and Nurhadi, Nurchasanah [4] classified the dimensions of thinking in three categories that are (1) literal thinking: identifying and remembering; (2) critical thinking: reorganizing, inferring, evaluating, and appreciating; and (3) creative thinking: creating, creating and changing. Nurchasanah's thinking construction is used as a foundation for data analysis of basic level (literal) representation in elementary thematic textbooks with the consideration that all levels of thinking can be identified through this level of thinking. This level of thinking behavior is more organized because it is classified in its level, especially the level of basic thinking (literal). Supriyono [14] reinforced that Barrett's level of thinking can measure students' intellectual and emotional competence.

Considering the background above, this study aims to describe the dimensions of basic level (literal) thinking in grade 1 and 2 elementary school textbooks in the hope that the results of this study can be utilized as consideration for the determination of textbooks that will be used as a means of student learning and a consideration for authors of books in next book writing.

\section{METHOD}

This study uses a qualitative approach [15] to the type of text content analysis research. The research data is in the form of a representation of basic level thinking in the thematic textbooks of class 1 and 2 elementary schools based on the 2013 curriculum published by the Ministry of Education and Culture revised edition 2017. Data was taken by documentation technique with the researchers' key instruments assisted by other instruments in the form of research implementation grids, data collection and presentation guidelines, data analysis guidelines, and data analysis results presentation tools. Data were analyzed using qualitative analysis techniques with the following procedures: (1) presentation of raw data in a data presentation table; (2) data reduction: selection, classification, and coding of data; (2) data analysis: identification and presentation of results in the yield presentation table; (3) inference of preliminary results to final results after triangulation and re-analysis; (4) and interpretation of results: interpretation of results to find meaning of findings based on theory and the results of previous similar studies. To guarantee the validity of the data and the results of the analysis researchers used triangulation and re-analysis.

\section{FINDINGS}

In accordance with the objectives of the study, the results of this study were in the form of a representation of basic level thinking in elementary school textbooks for early grades (Grades 1 and 2) which included (1) observing, (2) identifying, (3) remembering, (4) copying, and (5) composing. Each point was described below.

\subsection{Observing}

According to Kamus Besar Bahasa Indonesia, the word observewas'to see and pay close attention'. Elementary school textbooks represented the observing activities that were shown in Data $1-a-1 b$ below.

\section{Observing the Picture}

Data 1-a

\section{Ayo Mengamati}

Amati gambar berikut ini! Kapan

suasana seperti ini biasa kita lihat?Apa

ciri khas keadaan pagi hari? Kegiatan

apa saja yang biasa dilakukan di pagi hari?

\section{Observing Readings (Reading)}

Data 1-b

Ayo mengamati (Membaca)
Setiap hari, Siti mendapat uang
saku.Uang saku Siti terdiri atas
berbagai pecahan uang. Siti selalu
menyimpan sisa uang sakunya.

Data 1-a dan 1-b in italics sentences represented the demands of thinking in the form of observing objects. The observed objects were in the form of images and texts (to be read).

\subsection{Identifying}

The word identifying came from the word identification. According to Kamus Besar Bahasa Indonesia, it means (1) self-identification, selfevidence, (2) the determination of personal identities, objects, etc., and (3) the imagination of himself like another person he admired unconsciously. Based on the meaning of the word, the word identify had a meaning 'determined or established the identity (people, things, etc.). Elementary textbooks represented thinking activities in the level of identification that have variations as in Data $2 a-2 h$ below. 
Identifying Letters

Data 2-a

\section{Ayo bernyanyi}

Bernyanyi sambil Mengenal Huruf Ayo, mengenal huruf. Ayo, berlatih membaca. Nyanyikanlah bersama temanmu.

\section{Identifying Words}

Data 2-b

Simak cerita di atas!

Pelajari kata-kata berikut ini!

Bacalah dengan nyaring!

\begin{tabular}{|l|l|l|l|}
\hline sore & matahari & condong & udara \\
\hline sejuk & mengulang & pelajaran & bermain \\
\hline
\end{tabular}

Lalu temukan kata-kata tersebut pada tabel huruf di bawah ini!

Tariklah garis mendatar atau menurun pada kata itu!

$\begin{array}{llllllllll}\mathbf{x} & \mathbf{v} & \mathrm{m} & \mathbf{t} & \mathbf{p} & \mathbf{w} & \mathbf{g} & \mathbf{m} & \mathbf{y} & \mathbf{t} \\ \mathrm{m} & \mathbf{f} & \mathrm{e} & \mathbf{l} & \mathrm{s} & \mathbf{u} & \mathrm{u} & \mathbf{p} & \mathbf{h} & \mathbf{k} \\ \mathrm{a} & \mathbf{j} & \mathrm{n} & \mathrm{c} & \mathrm{o} & \mathrm{n} & \mathrm{d} & \mathrm{o} & \mathrm{n} & \mathrm{g} \\ \mathrm{t} & \mathbf{k} & \mathrm{y} & \mathrm{b} & \mathrm{r} & \mathbf{k} & \mathrm{a} & \mathbf{w} & \mathrm{n} & \mathbf{k} \\ \mathrm{a} & \mathbf{m} & \mathrm{i} & \mathbf{n} & \mathrm{e} & \mathbf{w} & \mathrm{r} & \mathbf{j} & \mathbf{l} & \mathbf{h} \\ \mathrm{h} & \mathbf{d} & \mathrm{r} & \mathrm{t} & \mathrm{j} & \mathrm{r} & \mathrm{a} & \mathbf{v} & \mathbf{c} & \mathbf{x} \\ \mathrm{a} & \mathbf{r} & \mathrm{a} & \mathbf{r} & \mathbf{n} & \mathbf{g} & \mathrm{m} & \mathbf{z} & \mathrm{d} & \mathbf{u} \\ \mathrm{r} & \mathrm{s} & \mathrm{m} & \mathbf{d} & \mathbf{b} & \mathrm{s} & \mathrm{q} & \mathrm{a} & \mathrm{i} & \mathbf{r} \\ \mathrm{i} & \mathrm{p} & \mathrm{e} & \mathrm{l} & \mathrm{a} & \mathrm{j} & \mathrm{a} & \mathrm{r} & \mathrm{a} & \mathrm{n} \\ \mathrm{f} & \mathbf{d} & \mathbf{g} & \mathbf{h} & \mathbf{j} & \mathrm{u} & \mathbf{j} & \mathbf{k} & \mathbf{l} & \mathbf{n} \\ \mathrm{s} & \mathbf{x} & \mathbf{a} & \mathbf{v} & \mathbf{h} & \mathrm{k} & \mathbf{b} & \mathbf{u} & \mathbf{k} & \mathbf{0}\end{array}$

\section{Identifying Sentences}

Data 2-c

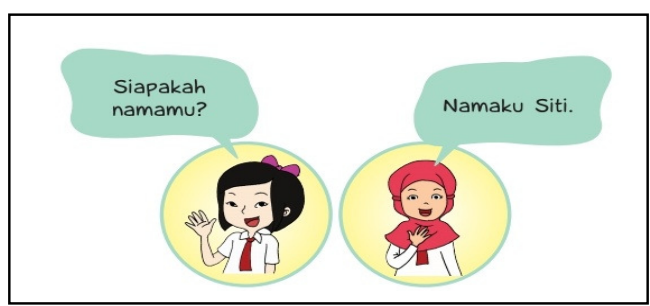

Perhatikan gambar di atas!

Siapakah yang sedang berkenalan?

\section{Identifying Sound}

Data 2-d

\section{Ayo berlatih}

Mengenal Warna Suara Teman Baru Siti berkenalan dengan teman baru. Siti berkenalan sambil bernyanyi. Ayo, dengarkan suara mereka! Suara teman-teman berbeda.
Itulah warna suara.

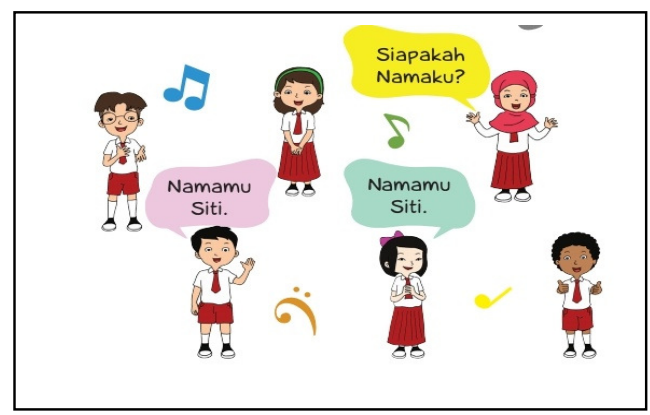

Identifying Movement

Data 2-e

\section{Ayo berlatih}

Bergerak Bersama Teman Amati gambar di bawah ini. Apakah yang sedang mereka lakukan?

Bagaimana mereka berjalan?

Lakukan bersama teman-temanmu.

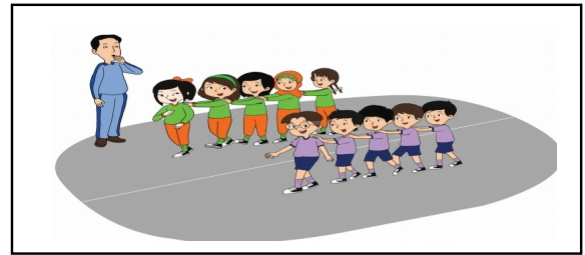

\section{Identifying Numbers}

Data 2-f

\section{Ayo mencoba}

Mengenal Bilangan Bersama Teman Baru Di kelas banyak teman baru. Ajak teman baru mengenal bilangan. Membilang gambar, lalu menyebut banyaknya.

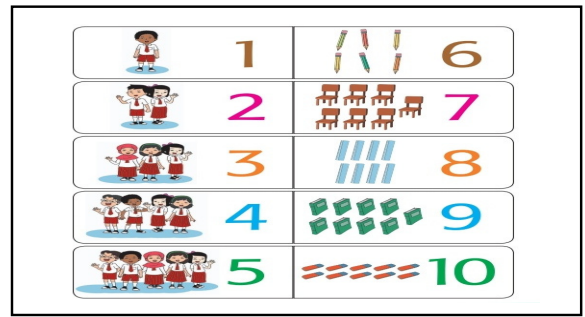

Identifying Actions (Greetings) Data 2-g

\section{Ayo mencoba}

Saat kita pulang sekolah. Ucapkan salam kepada guru dan teman-teman.

Besok bertemu lagi dengan mereka. Sampai di rumah, mengetuk pintu. Memberi salam kepada orang tua. Terima kasih Tuhan, saya sudah tiba di rumah. 

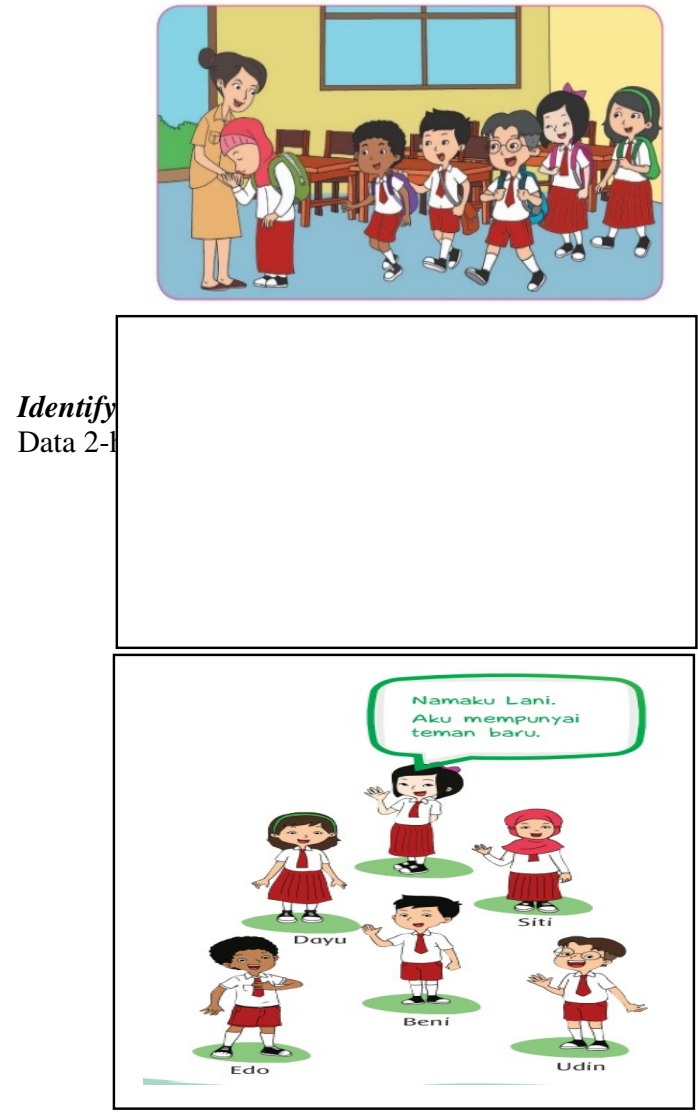

Data 2-a-2-h in italics sentences showed the demands of literal thinking at the identifying level. Students are invited to recognize and identify letters, words, sentences, sounds, movements, numbers, actions, and the environment aided by images.

\subsection{Remembering}

The word remembering came from the word remember which meant in Kamus Besar Bahasa Indoensia are (1) in the mind, not forgetting, (2) reappears in the mind, (3) conscious, sober, (4) paying attention, thinking about something. Based on the meaning of the word, it has the meaning 'calls back what's on the mind'. Elementary textbooks represented activities of thinking at the level of remembering that can be seen in Data 3-a-3-f below.

\section{Remembering the Laval}

Data 3-a

\section{Ayo Berlatih}

Perhatikan bunyi teksPancasila berikut ini. Pancasila

1. Ketuhanan Yang Maha Esa

2. Kemanusiaan yang adil dan beradab

3. Persatuan Indonesia

4. Kerakyatan yang dipimpin oleh hikmat kebijaksanaan dalam permusyawaratan/perwakilan
5. Keadilan sosial bagi seluruh rakyat Indonesia

Lafalkan bunyi teks Pancasila dengan lantang!

Bacakan di depan teman dan gurumu!

\section{Recalling the Reading Content Details}

Data 3-b

\section{a. Ayo berlatih}

Amati foto keluarga Udin.

Sebutkan namaayah Udin.

Sebutkan nama ibu Udin.

Sebutkan nama kakak Udin.

\section{b. Ayo Bercerita}

Apa isi lagu tersebut?

Siapa yang disayangi?

Diskusikan dengan temanmu.

Ceritakan hasil diskusi di depan kelas.

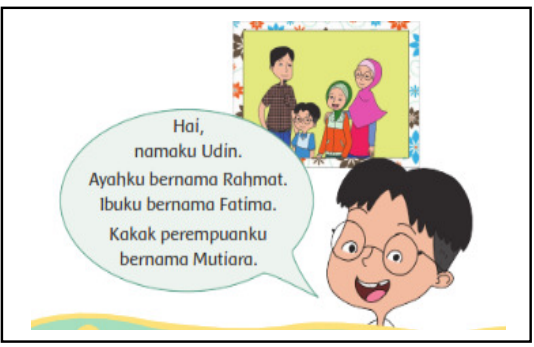

\section{Remembering Actions}

Data 3-c

Pernahkah kamu makan bersama adikmu? Apa saja yang kamu lakukan saat makan bersama adikmu?

\section{Remembering Relationships}

Data 3-d

Nah, coba kamu pasangkan bunyi teks Pancasila berikut ini dengan simbolnya. Buatlah garis untuk mencocokkannya.

Kemanusiaan yang adil dan beradab

Ketuhanan Yang Maha Esa

Persatuan Indonesia

Keadilan sosial bagi seluruh rakyat Indonesia

Kerakyatan yang dipimpin oleh hikmat kebijaksanaan dalam permusyawaratan/perwakilan 
Remembering the song

Data 3-e

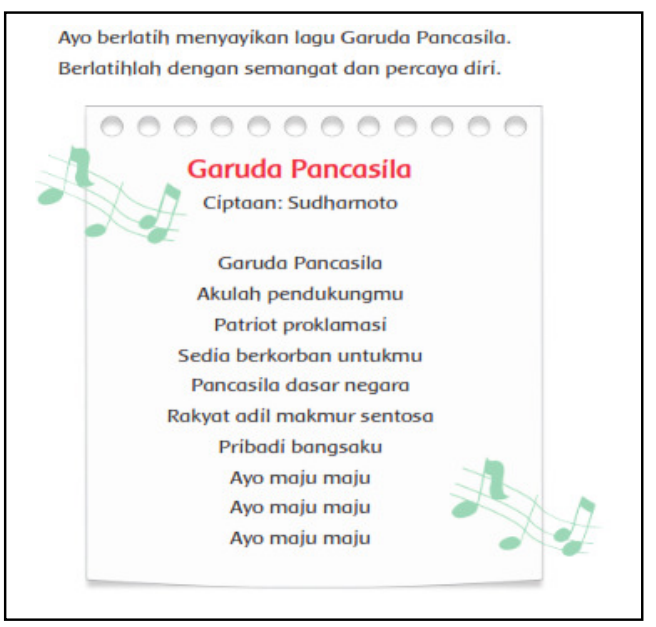

Remembering spelling

Data 3-f

\section{Ayo Berlatih}

Masih ingatkah kamu dengan aturan penggunaan huruf kapital?Huruf kapital digunakan pada awal kata nama orang dan nama tempat. Selain itu, penggunaan huruf kapital juga ditulis pada setiap awal kalimat. Sekarang, coba kerjakan latihan dengan mengikuti petunjuk berikut! • Bacalah kembali teks cerita "Pemuda Bersuling Ajaib"!

Temukan 5 kalimat dalam cerita yang di dalamnya memuat aturan penulisan huruf kapital!

- Tuliskan

hasilnya di bawah ini!

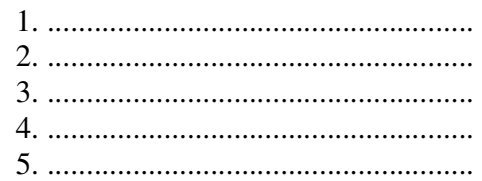

Data 3-a-3-f in italics sentences represented the activity of remembering. The questions and assignments represented in textbooks required students to answer them through the process of remembering something they have done. The demands of remembering had variations such as remembering (1) Laval, (2) detailed reading content, (3) actions, (4) relationships, (5) songs, and (6) spelling.

\subsection{Copying}

The word copying came from the word copy based on Kamus Besar Bahasa Indonesia that meant 'replace, exchange'. In this context, copying had the meaning of 'imitating or rewriting an article'. Elementary textbooks represented thinking activities at the copying level that can be seen in Data 4 below.
Data 4

Sekarang salinlah kalimat dari kata berikut!

Saya bangun pagi

Sesudah mandi Udin sarapan

Matahari pagi bersinar

Pagi ini Siti sarapan nasi goreng

Lani pergi ke sekolah sekolah

Pagi hari adalah waktu yang baik untuk belajar.

Rajinlah belajar agar menjadi anak pintar.

Data 4 represented the demands of thinking in the form of copying. Students were required to copy sentences that have been determined.

\subsection{Composing}

The word composing came from the word 'compose' which meant1) a little group, (2) a set of items (arranged) in stages, (3) double (which is overlap). Based on the word's meaning, the word composing had the meaning of 'arranging well'. Elementary textbooks represented the compilation activities shown in Data 5-a-5-b below.

\section{Arranging Letters into Words}

Data 5-a

Usai bermain tangkap bola Udin pulang ke rumah.

Udin segera mandi sore.

Setelah rapi Udin mengulang pelajaran membaca.

Udin belajar menyusun huruf menjadi kata. Ayo bantu Udin menyusun huruf menjadi kata!

S

o

E a

d

a

S e 


\section{Arrange Words into Sentences \\ Data 5-b}

\section{Ayo Berlatih}

Susunlah kartu-kartu kata berikut ini! Susunlah menjadi bunyi teks

Pancasila yang benar!
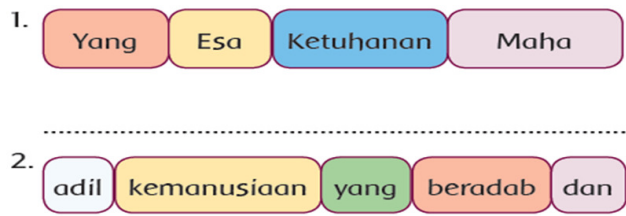

3.

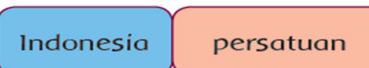

Data 5-a and 5-b in italics sentences represented composing activities. Letters and sentences in the lined box were not sequential. Students were asked to arrange them into meaningful words and sentences.

\section{DISCUSSION}

Thinking has a different gradation. In learning, the quality of thinking of students also has a different gradation. There are students who can only think at a basic level, some are already able to think up to a high level. Thinking at basic level is termed by Martutik, Nurchasanah, and Rani [6] in terms of literal thinking. Literal thinking is shown by the behavior of recognizing and remembering [4]. Literal understanding is characterized by thinking behaviors of explicit reading aspects [4 and 14]. Reading aspects that are identified and remembered explicitly are in reading. Supriyono [14] said that literal thinking can be shown by remembering the facts or events that have been done.

As the development of thinking training, Supriyono [14] said that according to Barret, literal thinking can be in the form of activities (1) identifying facts: the name and nature of the perpetrators, events, place of occurrence, time of events, and causes of events (Recognition of details), (2 ) identifying the main ideas of the reading/discourse that is written (Recognition of main ideas), (3) identifying and sorting the chronology of events or actions that are explicit (Recognition of a Sequence), (4) identifying or finding similarities and differences in the nature of the perpetrators, time, and an explicit place (Recognition of Comparison), (5) identifying or finding the reason or cause of an explicit event or action (Recognition of Cause and Effect Relationships), and (6) finding an explicit statement that helps us recognize the nature or type of perpetrators which is told in a reading/discourse (Recognition of Character Traits).

The results of the elementary school textbook analysis represent the demands of literal thinking in the form of
(1) observing, (2) identifying, (3) remembering, and (4) composing. Each is discussed in the following description.

Observing are classified to literal stage of thinking activities. All activities of learning always start from observing activities [16]. Observing in the context of a scientific approach based on the 2013 curriculum has a broad understanding. It can be observing with vision, hearing, smell, touch, and tasting [16]. Through observing, students are trained to search for information with full accuracy and seriousness [17]. Based on the results of elementary school textbook analysis, students are required to observe images and observe readings. The displayedimages are expected to be observed by students so they recognize the identity of the image. Reading has been provided and it is expected that students can practice reading. Based on Permendikbud No. 81a Th. 2013, observations train students to pay attention (see, read, hear) for important things from objects. The activity of observing reading (pictures) has actually been trained since kindergarten, as a result of research by Nurchasanah [18]. However, it seems that this learning continues until elementary school. It is assumed that reading activities are the basic skills that must be given to students at various levels of the school, only differing levels of reading difficulty.

Identifying is shown by recognizing behavior [4]. Objects that are recognized in elementary textbooks are letters, words, sentences, sounds, movements, numbers, actions, and environments aided by images. This was also proven by Nurchasanah's research [18], only the level studied was different, namely in kindergarten. By referring to Piaget's theory [19], the picture serves as a medium of realizing the development of elementary school children thinking at the level of concrete operations thinking (7-12years). Objects that are recognized are explicit [6]. Moreover, objects that are recognized areinvisible in text and images so it is classified as thinking at the literal level. Remembering is also classified as literal level thinking [4]. At this stage, students are required to reproduce what they had done and stored in memory [18]. The results of elementary school textbook analysis, students are required to remember (1) Laval, (2) detailed reading content, (3) actions, (4) relationships, (5) songs, and (6) spelling. This activity of remembering has actually been given when children study in kindergarten as a result of research by Nurchasanah [18]. What distinguishes is something that is remembered by elementary school children is more complex and wider reach than kindergarten children. According to Bloom's thinking,that activity is the most basic level of thinking [20]. Remembering is an activity that relies on memory [18]. Chaplin in 2002 stated that memory is a whole past experience that can be recalled [21]. It is important to knowthat the core of cognitive development is memory because all forms of individual learning always involve memory [21]. Memory relies on the brain's ability to process the storage and expression of all things that have been captured by the senses, which have been seen, heard, and felt significantly [22]. 
Composingare classified asliteral stage thinking activity. Examples of this activity are shown by the behavior of sorting letters that are not yet sorted into meaningful words and sorting words into sentences. Exercises like this have also been taught since children are in kindergarten as a result of research by Nurchasanah [18]. Because the ordered objects are concrete objects (letters and sentences), according to Piaget [19], these mental operations are thinking about the concrete operations stage. Students must have initial knowledge (Skemata) about words and their meanings and sentences to be able to arrange letters into them. It is shown that Piaget's schemata theory plays a role in constructing knowledge [19]. Without the initial knowledge already stored in memory, students will not be able to sort them into meaningful words and sentences. The behavior of remembering has the big effect on the activities of arranging letters into words and words into sentences. This remembering activity is called 'activation of memory [23]. If students' memories can be activated, students will be able to arrange letters into meaningful words and words into sentences.

Thinking activities such as observing, identifying, remembering, and compiling in elementary school textbook are proven to have been provided in kindergarten as stated in Nurchasanah's research [18] about kindergarten magazines. What is taught in primary school is not different from what is taught in kindergarten. Elementary school textbooks and kindergarten magazines as a source of student learning need to be reviewed so that (1) the material provided in elementary school is different from in kindergarten and (2) the material in elementary school should be one level higher than in kindergarten. The problem now is the early elementary school textbooks or kindergarten magazines that need to be addressed so that the teaching materials are in accordance with the development of student thinking.

\section{CONCLUSION}

Elementary school $1^{\text {st }}$ and $2^{\text {nd }}$ grade textbooks represent the demands of basic level (literal) thinking in various forms of training. Literal thinking representation has variations in the form of activities (1) observing, (2) identifying, (3) remembering, and (4) composing. All the exercises represented were guided by pictures as a manifestation that elementary students are at the level of concrete-thinking. Based on the results of previous studies, thinking exercises like that have been given also in kindergarten. Therefore, improvement of teaching materials is needed so that teaching materials in elementary schools are different from those given in kindergarten.

\section{ACKNOWLEDGEMENT}

Thank you to the Chairperson of LP2M State University of Malang (UM) and its staff, UM Officials and their staff, and the Director General of DRPM who facilitated this research activity.

\section{REFERENCES}

[1] Nurchasanah, Suyono, Lestari, and Habsari. Dimensions Of Knowledge in Indonesian Text Books For SMA/SMK Based Curriculum 2013. In ICHSS Conference, LP2M, UM. (2018), 22-23 September 2018.

[2] Eanes, R. Content Area Literacy: Teaching for Today and Tomorrow. Washington: ITP an International Thomson Publishing Company. (1997).

[3] Suyono. Pembelajaran Efektif dan Produktif Berbasis Literasi:Analisis Konteks, Prinsip, dan Wujud Alternatif Strategi Implementasinya di Kamput, (Online).http://sastra.um.ac.id/wpcontent/uploads/2012/01/9Suyono.docx.pdf. (2012), accessed $20^{\text {th }}$ January 2013.

[4] Nurchasanah. Membaca: Teks Ilmiah dan Nonilmiah. Malang: Universitas Negeri Malang. (2015).

[5] Nurhadi. (2009). Dasar-dasar Teori Membaca. Malang: Universitas Negeri Malang.

[6] Martutik, Nurchasanah, and Rani. Membaca Intensif. Unpublished arch report. Malang: LP2M. (2012).

[7] Kementerian Pendidikan dan Kebudayaan. Standar Proses Pembelajaran. Jakarta. (2016).

[8] Nurchasanah, Suyitno, and Suyono. Pepresentasi Tuntutan Berpikir dalam Buku Teks SMA Berbasis Kurikulum 2013. Unpublished research report. Malang: FS UM. (2017).

[9] Anglin, G.I. Instructional Technology. Colorado: Libraries Unlimited. Cunningsworth, A. 1995. Choosing your Coursebook. Macmillan Heineman. (1991).

[10] Cunningsworth, A. (1995). Choosing your Coursebook. Macmillan Heineman.

[11] Yustisia, A. Analisis Kesalahan dan Perbaikan pada Buku Teks Geografi SMA Kelas X Materi Hidrosfer. In Jurnal Geografi dan Pendidikan, Vol. 1, 3 January 2018, (Online). Retrieved from https://www.academia.edu/ 35608237/ANALISIS_KESALAHAN_ and_PERBAI KAN_PADA_BUKU_TEKS GEOGRAFI_SMA_KELAS. (2018), 
accessed $25^{\text {th }}$ March, 2019.

[12] Jana Stara, Martin Schval, and Carel Stary. The Role of Texbooks in Primary Education, (Online). Retrieved from https://www.researchgate.net/publication/ 333754687_The_Role_of_Textbooks in_Primary_Education, maccessed. (2017), accessed $24^{\text {th }}$ February, 2020.

[13] Barrett, T.J. Taxonomy of Reading Comprehension: Reading 360 of Monograph. Lexington, MA: Ginn and Co. (1972).

[14] Supriyono. Membimbing Siswa Membaca Cerdas dengan Taksonomi Barrett,(Online). Retrieved from https://docplayer.info/29912316Membimbing-siswa-membaca-cerdasdengan-taksonomi-barrett-drssupriyono-a-md-med-ket. (2016), accessed $23^{\text {th }}$ March, 2019.

[15] Bogdan, R. C. and Biklen. Qualitative Research for Education. Allyn and Bacon. Boston London Toronto, Sydney, Tokyo, Singapure. (1998).

[16] Endarta. Mengamati, (Online). Retrieved from http://duniapendidikan.putrautama.id/ mengamati/. (2016), accessed $27^{\text {th }}$ September 2019.

[17] Khoirunisa, R. Mengamati Menanya Eksplorasi Asosiasi dan Komunikasi dalam Metode Pembelajaran Ilmiah (Saintifik) Kurikulum 2013. (Online). Retrieved from http://referensisiswa.blogspot.com/2016/ 04/mengamati-menanyamengeksplorasi.html, (2016), accessed $27^{\text {th }}$ September, 2019.

[18] Nurchasanah. Representasi

Penanaman Perilaku dalam Bahasa Majalah TK. Dissertation not published. Malang: Pascasarjana Universitas Negeri Malang. (2011).

[19] Piaget, J. and Barbel Inhelder. The Psychology of the Child. New York: Basic Books, Inc. (1969).

[20] Gunawan and Palupi. Taksonomi Bloom-Revisi Ranah Kognitif: Kerangka Landasan untuk Pembelajaran,
Pengajaran, dan Penilaian, (Online). Retrieved from http://e journal.unipma.ac.id/index. php/PE/article/view/50. (2008), accessed $25^{\text {th }}$ February, 2020.

[21] Desmita. Psikologi Perkembangan. Bandung: PT Remaja Rosdakarya. (2008).

[22] Santoso, AM. Rukky. Mengembangkan Kemampuan Otak Kanan Anak-anak Jakarta: PT Gramedia Pustaka Utama. (2005).

[23] Robinson, P (Ed.). Individual Differences and Instructed Language Learning. Amsterdam/Philadelphia: John Benjamins Publishing Company. (2002). 